\title{
Highly Sensitive Electrochemical Determination of Dopamine with an Overoxidized Polypyrrole Nanofiber Pencil Graphite Electrode
}

\author{
Ozge Koyun ${ }^{1}$, Hurmus Gursu ${ }^{1,2}$, Semih Gorduk ${ }^{1}$ and Yucel Sahin ${ }^{1, *}$ \\ ${ }^{1}$ Department of Chemistry, Faculty of Arts \& Science, Yildiz Technical University, TR34210 Istanbul, \\ Turkey; \\ ${ }^{2}$ HMY Chemistry \& Energy Ltd. Company, TR34220 Esenler, Istanbul, Turkey; \\ *E-mail: yucelsahin06@gmail.com
}

doi: $10.20964 / 2017.07 .41$

Received: 5 April 2017 / Accepted: 8 May 2017 / Published: 12 June 2017

We investigated the use of an overoxidized nanofiber polypyrrole (OONfPPy) modified pencil graphite electrode (PGE) as a sensor for the determination of dopamine (DA) in this work. The performance of the modified electrode was studied using differential pulse voltammetric method. The surface of the modified electrode was characterized by an electrochemical impedance spectroscopy (EIS) and scanning electron microscope (SEM). The calculated electroactive areas of the bare electrode and $\mathrm{OO}_{10} \mathrm{NfPPy}_{5} \mathrm{PGE}$ were found to be $4.54 \times 10^{-8} \mathrm{~cm}^{2}$ and $1.05 \times 10^{-6} \mathrm{~cm}^{2}$, respectively. The sensor $\left(\mathrm{OO}_{10} \mathrm{NfPPy}_{5} \mathrm{PGE}\right)$ showed a high selectivity to DA with a detection limit of $6.95 \times 10^{-9} \mathrm{M}$ $(\mathrm{S} / \mathrm{N}=3)$. To demonstrate the validity of the sensor for the determination of DA, pharmaceutical and human serum samples were performed.

Keywords: Dopamine; Polypyrrole; Electropolymerization; Pencil Graphite Electrode; Sensor

\section{$\underline{\text { FULL TEXT }}$}

(C) 2017 The Authors. Published by ESG (www.electrochemsci.org). This article is an open access article distributed under the terms and conditions of the Creative Commons Attribution license (http://creativecommons.org/licenses/by/4.0/). 